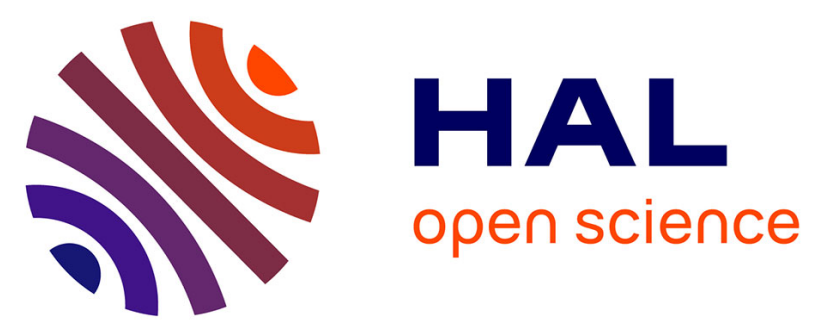

\title{
Research on Vegetation Ecologic Quality Index of Rocky Desertification in Karst Area of Guangxi Province Based on NPP and Fractional Vegetation Cover Since 2000
} Xin Yang, Haihong Huang, Shuan Qian, Hao Yan

\section{- To cite this version:}

Xin Yang, Haihong Huang, Shuan Qian, Hao Yan. Research on Vegetation Ecologic Quality Index of Rocky Desertification in Karst Area of Guangxi Province Based on NPP and Fractional Vegetation Cover Since 2000. 11th International Conference on Computer and Computing Technologies in Agriculture (CCTA), Aug 2017, Jilin, China. pp.225-230, 10.1007/978-3-030-06179-1_23 . hal-02111525

\author{
HAL Id: hal-02111525 \\ https://hal.inria.fr/hal-02111525
}

Submitted on 26 Apr 2019

HAL is a multi-disciplinary open access archive for the deposit and dissemination of scientific research documents, whether they are published or not. The documents may come from teaching and research institutions in France or abroad, or from public or private research centers.
L'archive ouverte pluridisciplinaire HAL, est destinée au dépôt et à la diffusion de documents scientifiques de niveau recherche, publiés ou non, émanant des établissements d'enseignement et de recherche français ou étrangers, des laboratoires publics ou privés. 


\title{
Research on vegetation ecologic quality index of rocky desertification in Karst area of Guangxi Province based on NPP and fractional vegetation cover since 2000
}

\author{
Xin Yang ${ }^{1,3}$, Haihong Huang ${ }^{1,3(\bowtie)}$, Shuan Qian $^{2}$, and Hao Yan ${ }^{2}$ \\ ${ }^{1}$ Remote Sensing Application and Test Base of National Satellite Meteorology Centre, \\ Nanning, China \\ ${ }^{2}$ National Meteorological Center of CMA, Beijing, China \\ ${ }^{3}$ Institute of Meteorological Disaster Mitigation, Nanning, China
}

\begin{abstract}
Karst rocky desertification is a kind of special and complicated surface form. Study established the Net primary productivity (NPP) estimation model based on the use of solar energy utilization of remote sensing data model in rocky desertification region of Guangxi province and the fractional vegetation cover(VFC) is obtained by the method of sub-pixel decomposition model. The comprehensive analysis method was used to establish vegetation ecologic quality index by using NPP and fractional vegetation cover to monitor the Rocky Desertification in the study area from 2000 to 2016, and mapping vegetation ecologic quality index grade classification. Results show that:1) In 2016, vegetation ecologic quality index in rocky desertification region of Guangxi province is 87.6, the highest since 2000. Hechi city is the best in Guangxi Province. 2)From 2000 to 2016, vegetation ecologic quality index annual growth has a 1.04, the highest is 87.6(in 2016) and the lowest is 63(in 2004). The ecological restorations and environmental control projects have achieved remarkable results. 3)Great grade、 Good grade and normal grade areas can account for $94.5 \%$. And vegetation ecologic quality index decreased obviously in some relative development regions, such as Guilin city and Hezhou city.
\end{abstract}

Keywords: Karst rocky desertification. vegetation ecologic quality index. NPP. fractional vegetation cover.

\section{Introduction}

Karst rocky desertification is a kind of special and complicated surface form, which is performance for the fragile ecological environment, and lead to the deterioration of regional ecological environment, so that drop the effective use of land resources, water resources have been destroyed, the survival of the foundation of the loss of biological resources. As an important index, NPP can reflect the changes of ecological environment; determine the ecosystem carbon source/sink effect. NPP is a key indicator of the terrestrial carbon cycle. The different ecological models have been obtained by many ecologists or researchers such as Coughlan 1988, Running and Nemani et al. 1993, ZhiQiang \& JiYuan 2008, BGC models. Currently, three BGC models are used. There are BIOME-BGC model, Terrestrial Ecosystem Model (TEM) and CENTURY model. Fractional vegetation cover is a key and land degradation. It is a very important parameter in developing climate and ecology model.

\footnotetext{
Institute of Meteorological Disaster Mitigation, Nanning, 530022, P. R. China, Tel: +86771-5865037, Fax: +86-771-5865594

NPP and VFC are very important parameters in developing climate and ecology model. Study established the NPP estimation model based on the use of solar energy utilization of remote sensing data model in rocky desertification region of Guangxi
} 
province and the VFC is obtained by the method of sub-pixel decomposition model. The comprehensive analysis method was used to establish vegetation ecologic quality index by using NPP and VFC to monitor the Rocky Desertification in the study area, and mapping vegetation ecologic quality index grade classification.

\section{Study Area and Data Used}

\subsection{Study Area}

Study Karst rocky area is located in Guangxi Province between $104^{\circ} 26$, E to $112^{\circ} 04^{\prime} \mathrm{E}$ and $20^{\circ} 54^{\prime} \mathrm{N}$ to $26^{\circ} 24^{\prime} \mathrm{N}$. The study zones are blue areas.

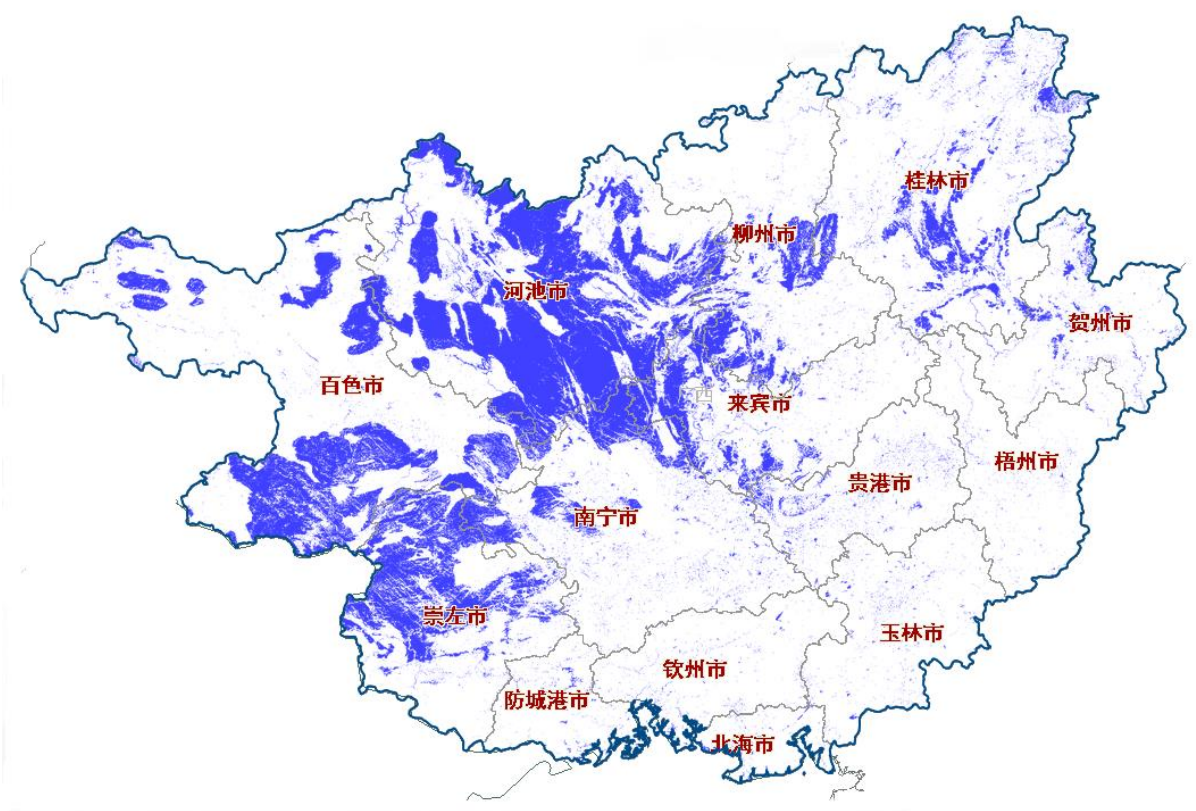

Fig. 1. Karst rocky areas of Guangxi Province

\subsection{Data List}

Table 1. Data list of Study.

\begin{tabular}{lll}
\hline Meteorological Data & Remote sensing data & Environmental background data \\
\hline Mean temperature & NDVI & Vegetation types \\
Sunshine duration & LST & Administrative divisions \\
Water-vapor pressure & & \\
Dew-point temperature & & \\
\hline
\end{tabular}




\section{$3 \quad$ Methodology}

NPP and VFC are very important parameters in developing climate and ecology model. The comprehensive analysis method was used to establish vegetation ecologic quality index by using NPP and fractional vegetation cover.

\subsection{NPP Calculate}

Our study was obtained by using seventeen-years historical data of NPP from NSMC (National Satellite Meteorological Centre) which obtained by using GloPEM model and extracted by using NOAA-AVHRR and MODIS data (2000-2016).

\subsection{Fractional Vegetation Cover Calculate}

Currently, field measurement method and remote sensing monitoring method are two methods of getting fractional vegetation cover. Field measurement method plays an important role in measure of fractional vegetation cover, which routinely widely used because of its high precision. However, this method is limited by bad weather, time and measure area condition. The method is also very expensive. With the development of remote sensing technique, remote sensing monitoring method in monitoring of fractional vegetation cover was provided. It possible to obtain fractional vegetation cover and its dynamic change in a large area, because remote sensing has the characteristics of periodic detection and large scale. The method has been widely used. In our study, pixel unmixing model was used to extract fractional vegetation cover because of its practical feature and simple. The VFC was modelled as:

$$
\text { VFC }=(\text { NDVI }- \text { NDVIsoil }) /(\text { NDVIveg }- \text { NDVIsoil })
$$

in which:

NDVIsoil=(VFCmax*NDVImin - VFCmin*NDVImax $) /($ VFCmax $-V F C m i n)$

NDVIveg $=((1-$ VFCmin $) * N D V I m a x-(1-V F C \max ) * N D V I m i n) /($ VFCmax - VFCmin $)$

\subsection{Vegetation Ecologic Quality Index Calculate}

The vegetation ecologic quality index(VEQI) was generated by using 17-years records of annual NPP and VFC values of rocky desertification in Karst area of Guangxi Province. The pixel level estimated trend analysis was generated by using geostatistical method. The vegetation ecologic quality index trend of annual NPP was modelled as.

$$
V E Q I=N P P t+V F C t
$$




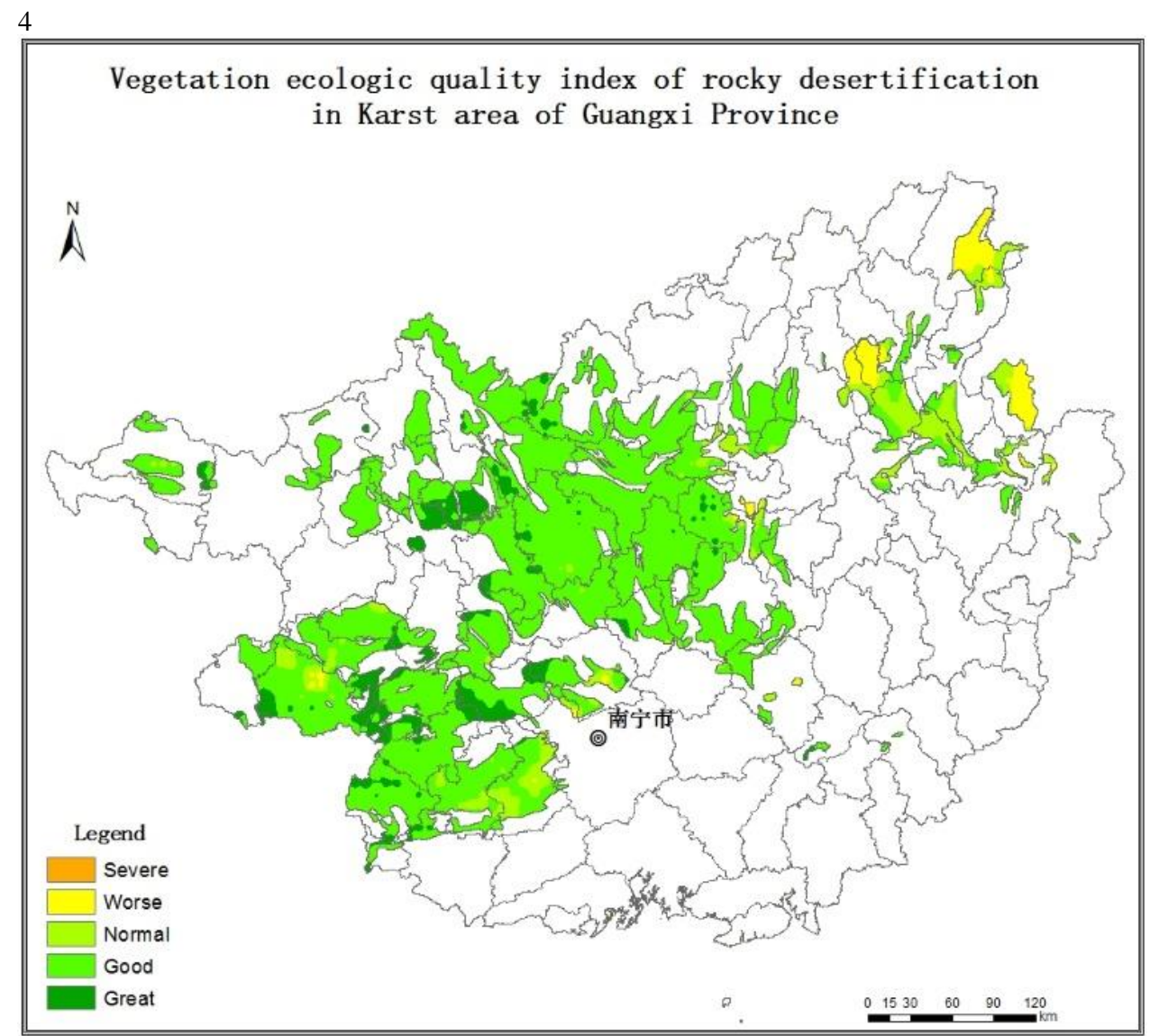

Fig. 2. Vegetation ecologic quality index of rocky desertification in Karst area in 2016

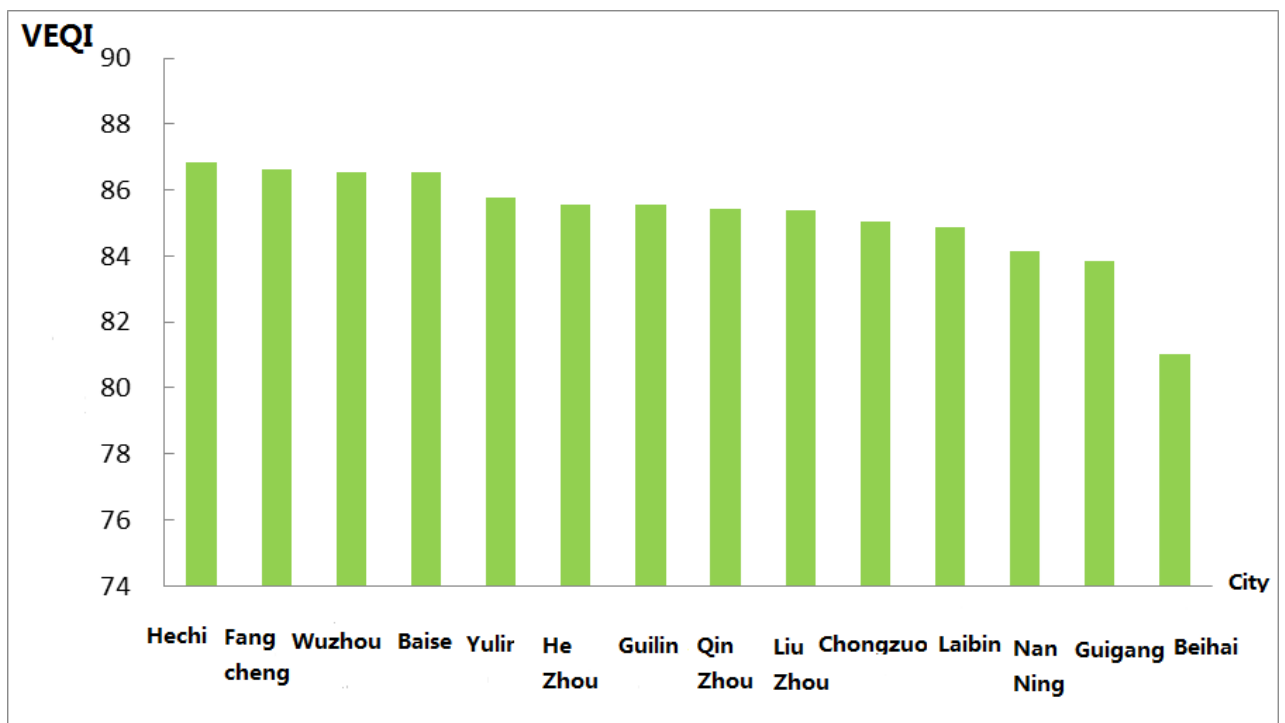

Fig. 3. Vegetation ecologic quality index of rocky desertification in Karst area of 14 cities in 2016 


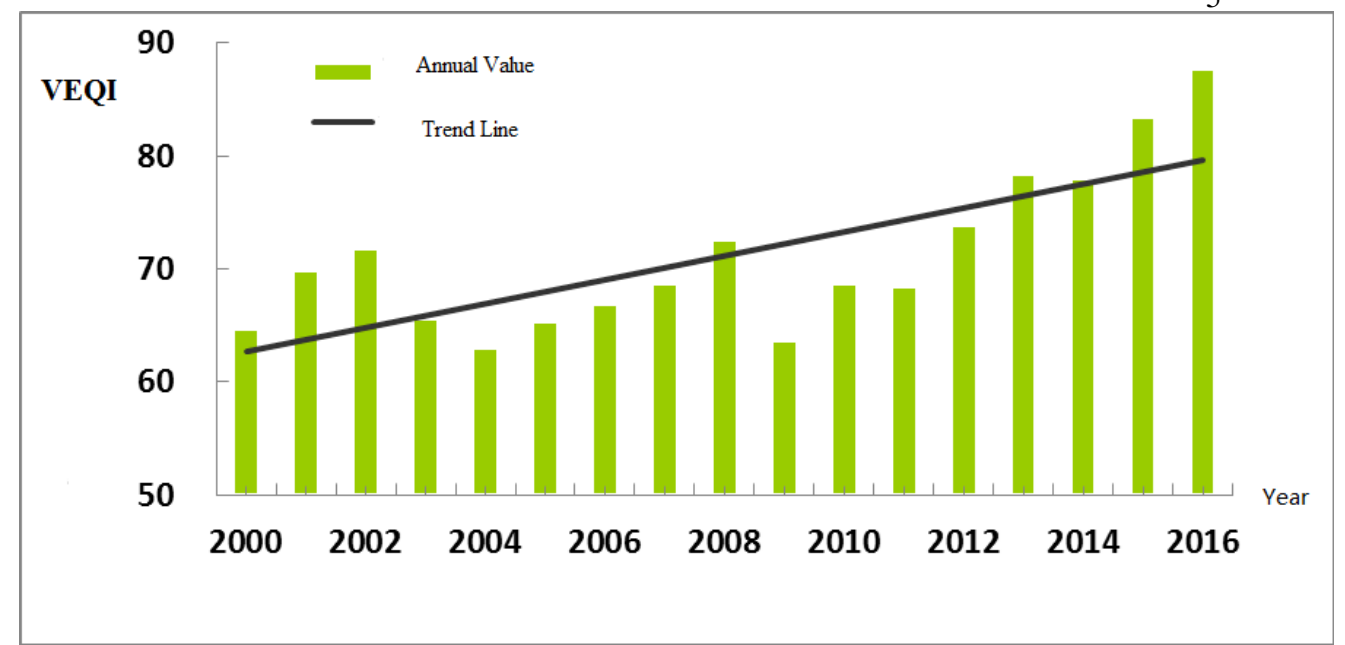

Fig. 4. Vegetation ecologic quality index of rocky desertification in Karst area from 2000 to2016

\section{$4 \quad$ Result and Discussion}

By analyzing the Vegetation ecologic quality index (Fig. 2、Fig. 3 and Fig. 4) of rocky desertification in Karst area of Guangxi Province.

1)In 2016, vegetation ecologic quality index in rocky desertification region of Guangxi province is 87.6, the highest since 2000.Hechi city is the best in Guangxi Province.

2)From 2000 to 2016, vegetation ecologic quality index annual growth has a 1.04, the highest is 87.6(in 2016) and the lowest is 63(in 2004). The ecological restorations and environmental control projects have achieved remarkable results.

3)Great grade 、 Good grade and normal grade areas can account for 94.5\%. And vegetation ecologic quality index decreased obviously in some relative development regions, such as Guilin city and Hezhou city.

Acknowledgements. This research was supported by Special Fund for meteorological scientific Research in the Public Interest (GYHY201506017). Sincerely thanks are also due to Guangxi Climate center and National Satellite Meteorology Center for providing the data for this study.

\section{References}

1. Bonan, G.B.: Forest and Climate Chane: Forcings, Feedbacks, and the Climate Benefits of Forest. Science 320, p. 1444 (2008)

2. Chhabra A. and Dadhwal V. K.: Estimating terrestrial net primary productivity over India using satellite data. Current Science, vol. 86, no. 2, p. 269 (2004) Foster, I., Kesselman, C.: The Grid: Blueprint for a New Computing Infrastructure. Mor- gan Kaufmann, San Francisco (1999)

3. Goetz, S. J. Prince, S.P., Smell J. and Gleason. Inter annual variability of global terrestrial primary production: results of a model driven with global satellite observations, Journal of Geophysical research, 105 (D15), 20077-20091(2000) 
4. Fang, J., Piao, S., Tang, Z., Peng, C., Ji W. Inter annual Variability in Net Primary Production and Precipitation Science 293, p. 1723 (2001)

5. Knapp, K., Smith, M. D.: Variation Among Biomes in Temporal Dynamics of Aboveground Primary Production Science 291, p. 481 (2001)

6. Kumar, M. and Monteith, J.L. Remote Sensing of crop growth. In:H,Smith (ed.), Plants and the daylight spectrum. Academic Press, London, pp. 133-144 (1981)

7. Nemani, R. R., Keeling C. D., Hashimoto, H., Jolly, W.M., Piper, S.C., Tucker, C.J., Myneni, R. B., Running, S.W (2003)

8. Climate-Driven Increases in Global Terrestrial Net Primary Production from 1982 to 1999 Science 300, p. 1560

9. Nemani, R., Running, S.W, Band, L.E., Peterson, D.L.: Regional hydroecological simulation system: an illustration of the integration of ecosystem models in a GIS. In: M.F. Goodchild, B.O. Parks and L.T. Steyaert (Editors), Environmental modeling with GIS. Oxford University Press, New York, pp. 296-304(1993)

10. Panigrahy, R. K., Panigrahy, S., Parihar, J. S.: SpatioTemporal Pattern of Agro Ecosystem Net Primary Productivity of India: A Preliminary Analysis Using Spot Vgt Data. Int. Symp. on Geospatial Databases for Sustainable Development, Goa, Vol. 36, Part 4, pp. 724-729 (2004)

11. Prince, S. D.: A model of regional primary production to use with coarse resolution satellite data, International Journal of Remote Sensing, 12(6), 1313-1330(1991)

12. Prince, S.D. Goward S.J.: Global primary production: a remote sensing approach, Journal of Biogeography, 22, 316336(1995)

13. Running, S.W. Gower, S.T., FOREST BGC, A general model of forest ecosystem processes for regional applications. II. Dynamic carbon allocation and nitrogen budgets. Tree Physiology 9: 147-160(1991)

14. Running, S.W., Coughlan, J.C.: A general model of forest ecosystem processes for regional applications. I. Hydrological balance, canopy gas exchange and primary production processes. Ecological Modelling 42: 125-154(1988)

15. Sabbe, H., Veroustraete, F. Estimation of Net Primary and Net Ecosystem Productivity of European terrestrial ecosystems by means of the C-Fix model and NOAA/AVHRR data VEGETATION 2000 conference, 2 years of operation to prepare the future, pp. 95-99. Space Application Institute, Joint Research Center, 21020 Ispra, Varese-Italy (200)

16.ZhiQiang, G. JiYuan, L. Simulation study of China's net primary production Chinese Science Bulletin February 2008(2008) 